\title{
Common principles and intermediates of viral protein-mediated fusion: the HIV-I paradigm Gregory B Melikyan
}

Address: Institute of Human Virology, Department of Microbiology and Immunology, University of Maryland School of Medicine, 725 W.
Lombard St, Baltimore, MD 21201, USA

Email: Gregory B Melikyan - gmelikian@ihv.umaryland.edu

Published: 10 December 2008

Retrovirology 2008, 5:III doi:10.1186/1742-4690-5-III

This article is available from: http://www.retrovirology.com/content/5/I/III

(C) 2008 Melikyan; licensee BioMed Central Ltd.

This is an Open Access article distributed under the terms of the Creative Commons Attribution License (http://creativecommons.org/licenses/by/2.0), which permits unrestricted use, distribution, and reproduction in any medium, provided the original work is properly cited.
Received: II November 2008

Accepted: 10 December 2008

\begin{abstract}
Enveloped viruses encode specialized fusion proteins which promote the merger of viral and cell membranes, permitting the cytosolic release of the viral cores. Understanding the molecular details of this process is essential for antiviral strategies. Recent structural studies revealed a stunning diversity of viral fusion proteins in their native state. In spite of this diversity, the post-fusion structures of these proteins share a common trimeric hairpin motif in which the amino- and carboxy-terminal hydrophobic domains are positioned at the same end of a rod-shaped molecule. The converging hairpin motif, along with biochemical and functional data, implies that disparate viral proteins promote membrane merger via a universal "cast-and-fold" mechanism. According to this model, fusion proteins first anchor themselves to the target membrane through their hydrophobic segments and then fold back, bringing the viral and cellular membranes together and forcing their merger. However, the pathways of protein refolding and the mechanism by which this refolding is coupled to membrane rearrangements are still not understood. The availability of specific inhibitors targeting distinct steps of HIV-I entry permitted the identification of key conformational states of its envelope glycoprotein en route to fusion. These studies provided functional evidence for the direct engagement of the target membrane by HIV-I envelope glycoprotein prior to fusion and revealed the role of partially folded pre-hairpin conformations in promoting the pore formation.
\end{abstract}

\section{Review}

Enveloped viruses initiate infection by fusing their membrane with the cell membrane and thereby depositing their genome into the cytosol. This membrane merger is catalyzed by specialized viral proteins referred to as fusion proteins. When activated via interactions with cellular receptors and/or by acidic endosomal $\mathrm{pH}$, these proteins promote membrane merger by undergoing complex conformational changes (reviewed in $[1,2]$ ). The principal challenges facing researchers studying molecular details of this process are: (i) limited structural information about fusion proteins and their refolding pathways; (ii) transient and generally irreversible nature of conformational changes; and (iii) often redundant number of proteins the majority of which may undergo off-pathway refolding. In spite of these obstacles, considerable progress has been made towards understanding viral fusion, as discussed in a number of excellent reviews [1-6]. The emerging picture is that disparate enveloped viruses have adapted a common strategy to fuse membranes. This review will discuss the general principles by which viral proteins promote fusion, focusing on the retroviral envelope (Env) glycoproteins exemplified by HIV-1 Env. 


\section{Intermediates of lipid bilayer fusion}

Whereas viral proteins regulate and promote the merger of biological membranes, complete fusion occurs when lipids from two distinct bilayers rearrange to form a continuous membrane. Thus, to elucidate the principles of protein-mediated fusion, it is essential to understand the mechanism of lipid bilayer fusion. The most prominent model for membrane fusion (Fig. 1A), referred to as the "stalk-pore" model [7], posits that contacting monolayers of two membranes are initially joined via a local saddleshaped connection referred to as a "stalk" [8,9]. Lateral expansion of the lipid stalk permits the distal monolayers to come into direct contact and form a shared hemifusion diaphragm. Accumulated evidence suggests that hemifusion is a common intermediate in a variety of proteinmediated fusion reactions (for review, see [10]). The subsequent rupture of a hemifusion diaphragm results in the formation of a fusion pore through which both membrane and content markers redistribute $[11,12]$.

\section{The structure-based classification of viral fusion proteins}

Generally, fusion proteins of enveloped viruses are type I integral membrane proteins expressed as trimers or dimers $[1-3,5,6]$. With a few exceptions, these proteins are rendered fusion-competent upon post-translational cleavage

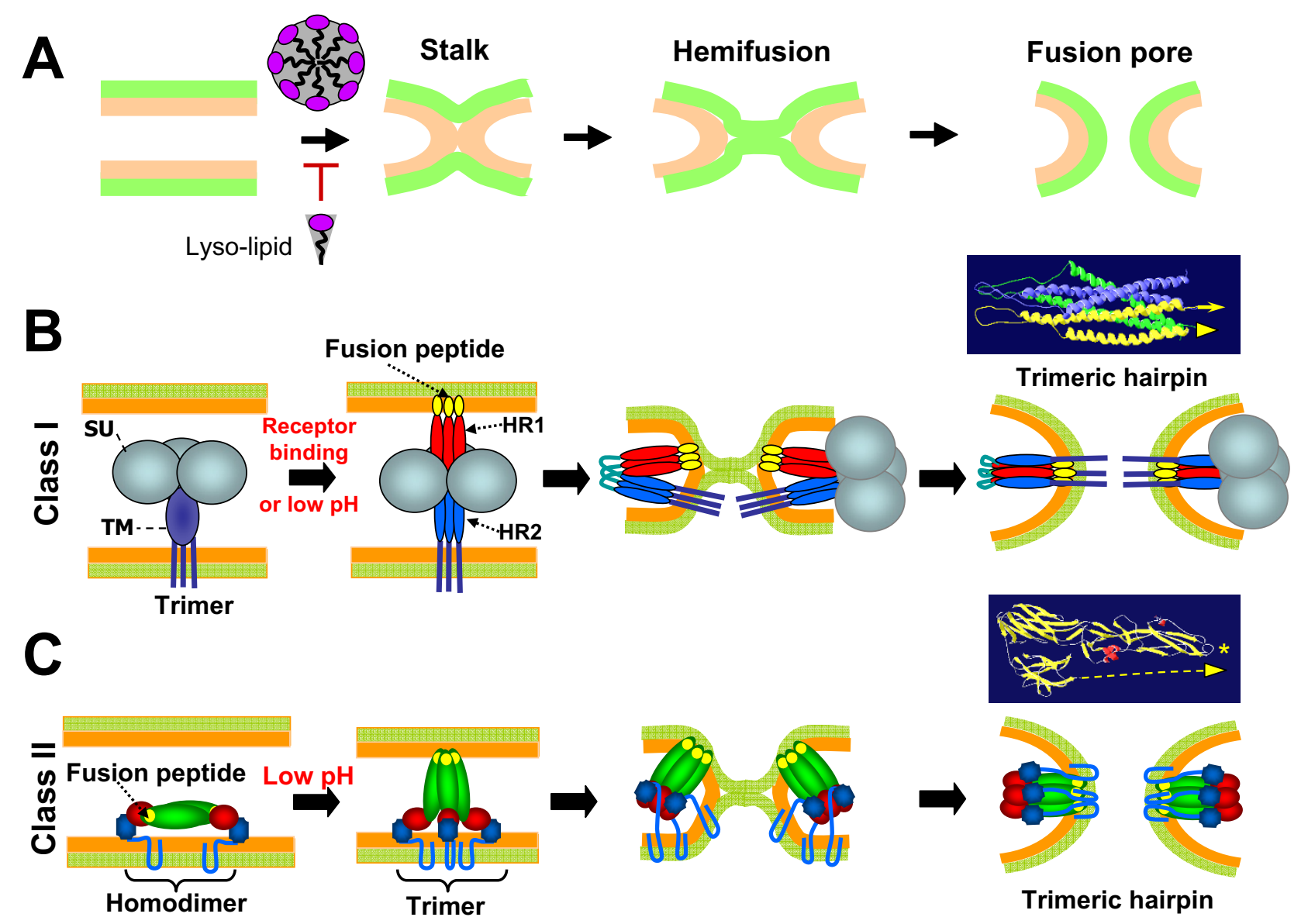

Figure I

The stalk-pore model of lipid bilayer fusion. $(\mathrm{A})$ and consensus models for class I and class II protein-mediated membrane fusion (B and C). SU and TM are the surface and transmembrane subunits of a fusion protein, respectively. Fusion peptides/domains are colored yellow. The structure in B is the trimeric core of the Simian Immunodeficiency Virus gP4I in a postfusion conformation. The yellow triangle and arrow represent the position and orientation of the membrane spanning domain and the fusion peptide, respectively. The structure in $C$ is the Dengue Virus $E$ protein fragment in its post-fusion conformation (a monomer is shown for visual clarity). The yellow dashed line and triangle represent the viral membrane-proximal segment and the membrane spanning domain, respectively. Asterisk marks the location of the fusion domain. 
by cellular proteases of either the protein itself or of an associated regulatory protein $[1,2,13]$. A salient feature of viral proteins is a highly conserved, functionally important stretch of hydrophobic residues referred to as the fusion peptide or the fusion domain $[1,13,14]$. In their mature, proteolytically cleaved form viral fusion proteins are thought to exist in a meta-stable, "spring-loaded" conformation [15], capable of releasing the energy as they transition to final conformation. While it is likely that this conformational energy drives fusion, the exact mechanism of coupling between protein refolding and membrane rearrangements is not fully understood.

Based on the structure of extracellular domains, viral fusion proteins are currently categorized into three classes. Fusion proteins of retroviruses, filoviruses, coronaviruses, ortho- and paramyxoviruses displaying a prevalent $\alpha$-helical motif belong to the class I proteins $[1,16,17]$. In an initial conformation, the $\mathrm{N}$-terminal or $\mathrm{N}$-proximal hydrophobic fusion peptides of the TM subunit (Fig. 1B) are usually sequestered at the trimer interface. Perhaps the best studied representatives of the class I proteins are influenza hemagglutinin and HIV-1 envelope (Env) glycoprotein (reviewed in $[18,19]$ ). The defining feature of the class II fusion proteins of flaviviruses and togaviruses is the predominant $\beta$-sheet motif $[1,3]$. These fusogens are expressed as homo-dimers (tick-borne encephalitis virus E protein) or hetero-dimers (Semliki Forest Virus E1/E2 proteins) with their hydrophobic fusion domains sequestered from solution at the dimer interface (Fig. 1C). The newly identified class III viral proteins (rhabdoviruses and herpesviruses) exhibit both $\alpha$-helical and $\beta$-sheet elements and thus appear to combine the structural features of first two classes $[1,5,6]$. Interestingly, fusion proteins of rhabdoviruses exemplified by the $G$ protein of Vesicular Stomatitis Virus (VSV) undergo low pH-dependent transition from a pre-fusion to a post-fusion form, but, unlike other viral proteins, return to their initial conformation at neutral $\mathrm{pH}[20,21]$. This unique reversibility implies that the difference in free energy of pre- and post-fusion conformations of $\mathrm{G}$ proteins is relatively small. Thus, the prefusion structure of this protein may not be viewed as meta-stable, suggesting that the "spring-loaded" mechanism [15] that relies on large changes in the protein's free energy may not be operational here [20].

\section{Model systems for studying viral fusion}

While the structures of ectodomains (or their core fragments) have been solved for several viral proteins, information regarding intermediate conformations of fulllength viral proteins in the context of fusing membranes is not available. Complementary functional assays are thus important for gaining insight into the refolding pathways of viral proteins. Mechanistic studies of viral fusion have been primarily carried out using a cell-cell fusion model $[11,22,23]$. Cell-cell fusion assays adequately reflect the activity of viral proteins, especially when early manifestations of fusion, such as small pore formation, are being monitored. Further, this model is ideally suited for manipulating experimental conditions and for convenient and reliable quantification of fusion products. However, there is increasing awareness of the fact that not all features of virus-cell fusion can be faithfully reproduced in this model. For instance, murine leukemia virus (MLV) undergoes receptor-mediated translocation ("surfing") along microvilli to a cell body before fusing to a plasma membrane [24]. An example of cellular compartment-specific entry is Ebola virus fusion that occurs after the cleavage of its glycoprotein by the lysosome-resident cathepsin B $[25,26]$. This intracellular activation of the fusion protein makes the cell-cell fusion model unsuitable for functional studies. The use of cell-cell fusion assays is also limited when surface expression of viral fusion proteins is low due to an endoplasmic reticulum retention signal. Examples of such glycoproteins include the Dengue Virus E [27] and Hepatitis C Virus E1/E2 [28] glycoproteins.

Until recently, direct techniques to measure virus-cell fusion were not available, and most functional studies employed infectivity assays to evaluate fusion [29-32]. However, measuring the levels of infection that rely on successful completion of viral replication steps downstream of fusion may underestimate the efficacy of fusion $[33,34]$. Novel techniques monitoring the delivery of viral core-associated enzyme into a host cell permit direct assessment of the extent and kinetics of virus-cell fusion [33-37], but these assays have limited sensitivity and temporal resolution. A powerful approach to study virus-cell fusion that circumvents fundamental limitations imposed by the heterogeneity of virus population is time-resolved imaging of single viral particles (e.g., [38-43]). Using this technique, important advances have been made towards understanding the mechanisms of receptor-mediated virus uptake, endosomal sorting, and towards identifying the preferred sites of virus entry [44-47]. Time-resolved imaging of viral lipid and content redistribution permitted visualization of intermediate steps of fusion between single HIV-1 and Avian Sarcoma and Leukosis Virus (ASLV) particles and target cells $[48,49]$.

\section{Entry pathways and modes of activation}

Viral proteins are activated through various mechanisms principally determined by the virus entry pathway $[1,22,39,41,50]$. Viruses that do not rely on low $\mathrm{pH}$ for entry are activated by binding to their cognate receptor(s) $[51,52]$ and are thought to fuse directly with a plasma membrane. Fusion proteins of viruses entering cells via an endocytic pathway are mainly triggered by acidic $\mathrm{pH}$ in endosomes $[1,39]$. These viruses often use cellular recep- 
tors as attachment factors to facilitate their internalization. Interestingly, ASLV Env is activated via the two-step mechanism that involves binding the cognate receptor that renders Env competent to undergo conformational changes upon subsequent exposure to low $\mathrm{pH}$ in endosomes [53-59]. The two-step activation of viral fusogens is not uncommon. HIV Env is rendered fusogenic through sequential interactions with CD4 and a coreceptor $[51,60]$. Following receptor-mediated endocytosis, the Ebola virus glycoprotein is activated by proteolytic cleavage in lysosomes $[25,26]$. These multiple triggering steps may help sequester the conserved functional domains of viral fusion proteins from immune surveillance and/or ensure the release of the viral genome at preferred cellular sites.

\section{A generalized mechanism of viral fusion}

In spite of structural differences, different classes of fusion proteins appear to promote membrane merger through a common "cast-and-fold" mechanism (reviewed in [1$6,11,16,22,23,61])$. The critical evidence supporting this universal fusion mechanism is the conserved trimeric hairpin (or 6-helix bundle, 6HB) motif shared by postfusion conformations of disparate viral proteins $[1,6,16,17]$. For class I fusion proteins, this structure is formed by antiparallel assembly of the central N-terminal trimeric coiled coil (or heptad repeat 1, HR1 domain) and three peripheral C-terminal helices (HR2 domains), as depicted in Fig. 1B. The antiparallel orientation of the Cterminal and N-terminal segments of ectodomains of class II and III viral proteins indicates that these proteins also form trimeric hairpin structures (Fig. 1C). An important implication of a hairpin structure is that, in the final conformation, the membrane-spanning domains (MSDs) and the hydrophobic fusion peptides, which are not a part of crystal structure, are positioned close to each other.

The following consensus model for viral protein-mediated fusion has emerged from the implicit proximity of the MSDs and fusion peptides in the conserved hairpin structures and from extensive biochemical and functional data (Fig. 1B, C). When triggered by receptor binding and/ or by low $\mathrm{pH}$, viral proteins insert their fusion peptides into a target membrane [62-66]. At this point, the initially dimeric class II proteins convert to fusion-competent homotrimers $[3,6,13]$. In addition to anchoring the viral proteins to the target membrane, the fusion peptides appear to destabilize lipid bilayers by promoting the formation of non-lamellar structures [14,67-69]. Next, the extended trimeric conformation bridging the viral and target membranes drives membrane merger by folding back on itself and forming a hairpin structure. Several lines of genetic and functional evidence support this model. First, mutations in the conserved fusion peptides [70-77] and those destabilizing the trimeric hairpin [78-82] attenuate or abrogate fusion. Second, peptides derived from the HR1 and HR2 regions of class I proteins (referred to as Cand N-peptides, respectively) inhibit fusion by binding to their complementary domains on the fusion protein and preventing $6 \mathrm{HB}$ formation (reviewed in [16]). Likewise, soluble fragments of class II fusogens also block fusion [83], apparently by preventing the formation of trimeric hairpins.

The general principles by which viral proteins cause membrane fusion are likely dictated by the physical properties of lipid bilayers which must form highly curved and thus energetically unfavorable intermediate structures (e.g., a stalk and a fusion pore). Accumulating evidence that fusion induced by distinct classes of viral proteins converges to a common hemifusion intermediate $[49,56,84$ 89] further supports the universal mechanism of membrane merger.

While it is widely accepted that the transition from an initial conformation to a final hairpin drives fusion, the refolding pathways of viral proteins are poorly characterized. In discussing the conformational intermediates of class I viral proteins, this review will focus primarily on fusion induced by HIV-1 Env. Numerous antibodies to HIV-1 Env and entry inhibitors targeting the receptor binding and fusion steps are available for mechanistic studies of Env-mediated fusion. Recent functional work using various HIV fusion inhibitors provided new clues regarding the HIV entry process.

\section{Conformational changes of class I proteins: Lessons from HIV-I Env-induced fusion Receptor binding and conformational changes in HIV-I gp/ 20 subunit}

The transmembrane, gp41, and surface, gp120, subunits of HIV Env are generated upon cleavage of the gp160 precursor by furin-like proteases. Mature HIV Env is rendered fusogenic upon sequential interactions of gp120 with CD4 and coreceptors, CCR5 or CXCR4 [16,18,51,90]. Binding to CD4 alters the structure and conformational flexibility of gp120 resulting in formation of the coreceptor binding site that permits assembly of ternary gp120CD4-coreceptor complexes [91-97]. Interestingly, Env glycoproteins from HIV-2 strains tend to undergo CD4induced conformational changes and engage coreceptors much faster than HIV-1 Env [98]. The assembly of ternary complexes, in turn, triggers gp 41 conformational changes culminating in formation of $6 \mathrm{HBs}$ in which the HR2 domains are packed in antiparallel orientation against the trimeric HR1 coiled coil (e.g., [16,17]).

The minimum number of CD4 and coreceptor molecules per Env trimer required to trigger fusogenic conformational changes has not been unambiguously determined 
[99-101]. Analysis of infection as a function of coreceptor density indicates that recruitment of 4-6 mutant CCR5 with attenuated affinity to gp120 per virion leads to infection [102]. On the other hand, the follow-up study using cells expressing CD4 and wild-type CCR5 concluded that recruitment of just one CCR5 molecule by CD4-bound Env could mediate infection [103]. However, clustering of HIV receptors within the membrane domains and modulation of HIV entry/fusion by homo-dimerization of CD4 and coreceptors $[104,105]$ confound the determination of the requisite number of these molecules in a fusion complex. Recent evidence suggests that, in addition to CD4 and coreceptors, proteins catalyzing the thiol/disulfide exchange reaction play a role in triggering productive conformational changes in HIV-1 Env [106-109].

Little is known about the mechanism by which the formation of gp120-CD4-coreceptor complexes triggers refolding of gp41. The notion that gp120 has to detach from gp41 (termed gp120 shedding) in order to lift the restriction on gp41 refolding is a subject of debate [110-114]. While the relevance of complete gp 120 shedding to fusion has not been convincingly demonstrated, there is evidence that interactions between gp120 and gp41 must weaken in order to initiate fusion [115]. Introduction of a disulfide bond between non-covalently associated gp120 and gp41 subunits rendered Env inactive. However, this mutant could be re-activated by reducing the disulfide bond after allowing the Env to interact with CD4 and coreceptors on target cells. Under these conditions, reduction-induced fusion was resistant to coreceptor binding inhibitors, implying that the receptor/coreceptor binding function was not compromised by linking gp120 and gp41 subunits [115]. These findings suggest that, following the formation of ternary complexes with CD4 and coreceptor, gp 120 must, at least partially, disengage gp 41 to permit the fusogenic restructuring of the latter subunit.

\section{HIV-I gp4I refolding}

Two complementary approaches have been employed to follow the progression of gp 41 through intermediate conformations. The formation/exposure of novel gp41 epitopes has been assessed via antibody reactivity using an immunofluorescence assay or by measuring the binding of gp41-derived peptides to their complementary HR1/HR2 domains [116-119]. Alternatively, the exposure of the HR1 and HR2 domains has been indirectly detected based on the ability of gp41-derived inhibitory peptides to block the progression to full fusion after these peptides were introduced and washed off at an arrested intermediate stage [120-124] (see below). A set of gp41 conformations on which the HR1 and/or HR2 domains are exposed will hereafter be referred as pre-bundles [123].

\section{Exposure of gp4l epitopes}

Immunofluorescence experiments demonstrated that the gp41 HR1, as well as the immunogenic cluster I (residues 598-604) and cluster II (residues 644-663) overlapping the gp41 loop and HR2 domain, respectively, are transiently exposed during fusion [116-118]. The HR1, HR2 and loop domains become available as early as upon CD4 binding and are lost concomitant with the onset of cellcell fusion. By comparison, the tryptophan-rich membrane-proximal external region (MPER), which is C-terminal to the gp41 HR2 domain, is accessible to the neutralizing antibodies, 2F5 and 4E10, on the native structure, but the MPER accessibility is gradually lost as fusion progresses to the content mixing stage $[116,117,125]$. The exposure of HR1 and HR2 domains upon interactions with $\mathrm{CD} 4$ is also supported by the enhanced binding of $\mathrm{C}$ - and N-peptides targeting these domains $[117,119,126-128]$. To conclude, gp120-CD4 and gp120-coreceptor interactions reportedly result in (at least transient) exposure of HR1 and HR2 domains and in occlusion of the gp41 MPER.

It is worth emphasizing that antibody and peptide binding assays cannot differentiate between relevant conformations leading to fusion and off-pathway structures corresponding to an inactivated gp41. This notion is supported by the fact that antibodies against gp 41 pre-bundles have been reported to react with gp41 outside the contact area between Env-expressing and target cells [117] or under conditions promoting gp41 inactivation, e.g., after sCD4 treatment in the absence of target cells $[116,118]$. This consideration highlights the advantages of functional assays (see below) that monitor the sensitivity of different stages of fusion to inhibitory peptides blocking $6 \mathrm{HB}$ formation. By definition, functional assays monitor the conformational status of Env trimers that participate in productive fusion.

\section{Functional dissection of fusion intermediates}

A powerful approach to elucidate the mechanism of HIV1 Env-induced membrane merger involves dissection of individual steps of cell-cell [115,118,121-124,129-131] and virus-cell fusion $[29,48,49]$. This strategy is based upon capturing distinct intermediate stages of fusion and examining their resistance to inhibitors that target different steps of this reaction. As discussed above, the HR1 and HR2 domains are not exposed on a native gp 41 or on the final 6HB structure [132], but these domains are available on pre-bundles formed upon interactions with receptors and/or coreceptors $[122,126-128,130,133]$. The formation of gp41 pre-bundles has been indirectly demonstrated by the gain-of-function experiments using the gp41-derived inhibitory peptides. This approach is based upon the addition of inhibitory peptides at distinct intermediates stages and assessing the peptide-gp 41 binding 
by washing off the unbound peptide and restoring optimal conditions $[121,123,124,129,130]$. If this protocol attenuates the fusion activity, the complementary HR domains must have been exposed at a given intermediate stage. Conversely, the transition of gp41 pre-bundles to $6 \mathrm{HBs}$ can be detected using a loss-of-peptide-function assay (see below).

HIV-1 Env-mediated fusion is a steep function of temperature and is blocked at temperatures below a threshold value around $18-23^{\circ} \mathrm{C}$, depending on the viral strain and expression levels of Env, receptors and coreceptors $[122,124,134,135]$. Prolonged (several hours) pre-incubation of Env-expressing and target cells at sub-threshold temperature results in formation of the temperaturearrested stage, TAS [130]. As evidenced by the resistance to inhibitors of CD4 and coreceptor binding, the majority of functionally active Env form ternary complexes with receptors and coreceptors at TAS without promoting hemifusion or fusion [124]. Thus, formation of ternary gp120-CD4-coreceptor complexes can be readily isolated from the subsequent restructuring of gp4 1 that leads to a membrane merger. Even though fusion does not occur at TAS, the gp41 HR1 and HR2 domains are exposed at this stage, as evidenced by sensitivity of fusion to C- and $\mathrm{N}$ peptides added and washed off prior to raising the temperature $[122,130]$.

To identify the most advanced functional conformation of gp41 upstream of membrane merger, the fusion must be captured at physiological temperature. Disparate biological fusion reactions converge to a common lipid-dependent stage that can be reversibly blocked by incorporating lyso-lipids into the contacting leaflets of fusing membranes (reviewed in [136]). Lyso-lipids (e.g., lyso-phosphatidylcholine) inhibit fusion by disfavoring the lipid monolayer bending into a stalk intermediate (Fig. 1A). By taking advantage of the ability of lyso-lipids to reversibly block fusion upstream of membrane merger, HIV-1 Envinduced fusion has been captured at permissive temperature $[121,130]$. The $\mathrm{C}$ - and $\mathrm{N}$-peptides added at this intermediate stage termed a lipid-arrested stage (LAS) inhibited the fusion that would have otherwise occurred upon the removal of lyso-lipids. This finding demonstrates that gp41 does not form $6 \mathrm{HBs}$ prior to membrane merger even at optimal temperature.

The conformational status of gp41 at TAS and LAS upstream of membrane merger has been further characterized by employing C-peptides anchored to the target membrane through a short linker and a single transmembrane domain $[137,138]$. These spatially and orientationally constrained C-peptides were used to capture a subset of gp41 pre-bundles that directly engaged the target membrane [129]. These spatial constraints conferred selectivity to the anchored C-peptides permitting their interactions only with a subset of gp41 pre-bundles that inserted their fusion peptides into the target membrane (Fig. 2). Compared to control experiments when fusion was not interrupted, the inhibitory activity of membrane-anchored peptides observed upon restoring optimal conditions was greatly enhanced after creating LAS, but not after TAS. This implies that gp41 conformations captured at fusion-permissive temperature directly engage the target membrane, permitting ample time for binding of anchored C-peptides and thereby potentiating their inhibitory effect. The lack of direct interactions between gp41 and target membrane at sub-threshold temperature is supported by the lack of gp41 labeling at TAS by photoactivatable hydrophobic probe incorporated into target cells [139].

Considering the extreme stability of gp $416 \mathrm{HBs}$ in solution $[140,141]$, these structures should not readily regress back to pre-bundles and thus should not interact with soluble C- or N-peptides [133]. Therefore, the acquisition of resistance to soluble inhibitory peptides added at an advanced intermediate stage should herald the formation of a requisite number of $6 \mathrm{HBs}$ at the fusion site. This strategy revealed that gp 41 folding into the $6 \mathrm{HB}$ is completed after (but not before) the opening of a fusion pore [123]. Briefly, the addition of inhibitory peptides resulted in the quick and irreversible collapse of nascent pores arrested by lowering the temperature immediately after their formation. Thus, small pores are formed before a requisite number of gp41 completes refolding into the 6HB. This finding demonstrates that, contrary to a common perception, fusion pores are formed by gp41 pre-bundles, whereas 6 HBs may play a role in stabilizing and perhaps expanding nascent pores. The sensitivity of nascent pores to inhibitory peptides also implies that the fusogenic gp41 pre-bundles are reversible conformations and that fusion pores are energetically unfavorable structures, prone to closing without the supporting fusogenic proteins. In summary, studies of the resistance of various fusion intermediates to soluble and membrane-anchored C-peptides led to identification of three distinct gp41 prebundle intermediates - early, bridging and fusogenic prebundles (Fig. 2) [123,129,130].

\section{The role of $6 \mathrm{HB}$ formation in fusion induced by other class I viral proteins}

It is worth pointing out that $6 \mathrm{HBs}$ are only a part of the trimeric hairpin motif of class I proteins. There is evidence that regions outside the HR1/HR2 domains play a role in fusion. For instance, the membrane-proximal external region (MPER) and residues adjacent to the fusion peptide are essential for the formation and growth of a fusion pore mediated by HIV-1 Env and influenza hemagglutinin [78,142,143]. Interestingly, ASLV Env appears to form $6 \mathrm{HBs}$ at low $\mathrm{pH}$ prior to membrane merger, as evidenced 


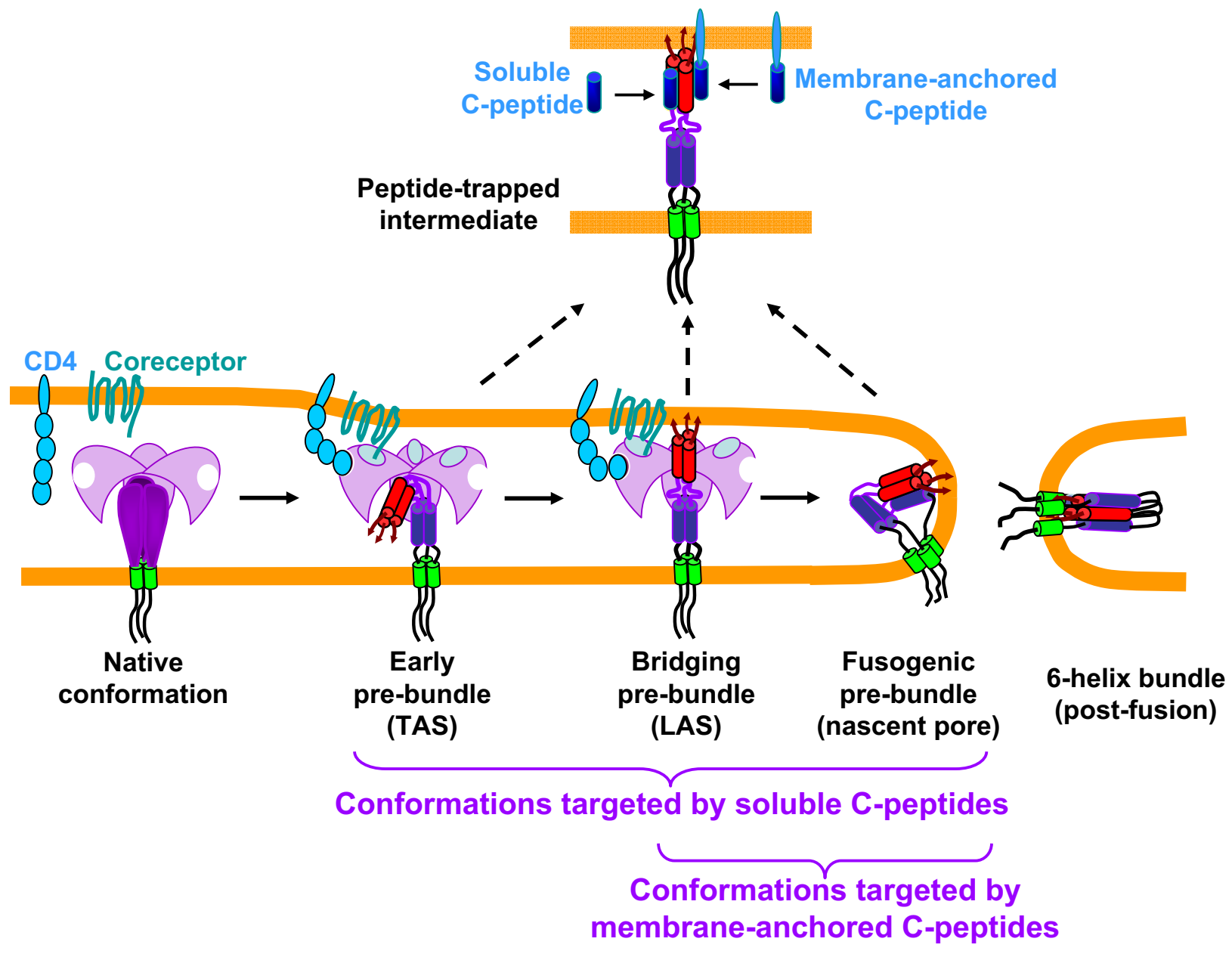

Figure 2

Intermediate steps of HIV-I Env-induced fusion progressing through early (TAS, temperature-arrested stage), bridging (LAS, lipid-arrested stage) and fusogenic pre-bundles toward 6-helix bundles that form after opening of a fusion pore. Membrane-anchored C-peptides capture the extended conformation of gP4I.

by resistance of fusion to the inhibitory HR2-derived peptide added at a lipid-arrested stage [144]. This finding suggests that, unlike the HIV-1 Env [123] and paramyxovirus $\mathrm{F}$ [145] glycoproteins, interactions between residues outside the ASLV heptad repeat domains are responsible for hemifusion and fusion. The degree of coupling between bundle formation and membrane merger may depend on the length and/or flexibility of a region between the HR2 and MSD. It thus appears that, in order to induce fusion, viral proteins must zipper completely and bring their membrane-anchored regions (MSDs and fusion peptides) into close proximity. Interactions between HR1 and HR2 domains within the $6 \mathrm{HB}$ may or may not provide the main driving force for a fully zippered structure. We and others [11,61] have hypothesized that fully assembled hairpins permit direct interactions between MSDs and fusion peptides, which may destabilize a hemifusion diaphragm and promote opening of a fusion pore (Fig. 1B).

\section{Pore growth and nucleocapsid delivery}

Dilation of fusion pores to sizes that permit viral nucleocapsid delivery $(\sim 50 \mathrm{~nm})$ is critical for infection, yet the mechanism of pore enlargement is not understood. Studies of influenza hemagglutinin and HIV Env-induced cellcell fusion showed that nascent pores are reversible structures sustained by fusion proteins [123]. Several lines of evidence suggest that the reliance on energy provided by viral proteins increases as fusion progresses from hemifu- 
sion to pore opening and pore enlargement steps $[78,84,123,146-150]$. First, the GPI-anchored ectodomain of influenza hemagglutinin is capable of promoting hemifusion and, with much lower probability, small nonenlarging pores $[148,151]$. In other words, lipid mixing can be readily achieved by the ectodomain anchored to the external leaflet of a plasma membrane, whereas a fulllength protein is required to form expanding pores. Second, complete fusion (content mixing) appears to require a greater density of active proteins compared to hemifusion (lipid mixing) $[48,84,147,150]$. Third, the number of cell pairs exhibiting lipid mixing is usually greater than those forming small fusion pores, and only a minor fraction of nascent pores enlarge $[148,152]$. These observations support the notion that formation, and especially dilation, of small pores is energetically unfavorable compared to hemifusion. Thus, a greater number of active fusion proteins is required to form and sustain functional pores.

The above considerations and several lines of functional evidence $[20,153-156]$ indicate that successful fusion is achieved through the concerted action of several viral proteins. For those class I proteins that exhibit strict coupling between $6 \mathrm{HB}$ formation and membrane merger $[123,130,157]$, pore growth could occur through recruiting additional proteins into its edge [123]. The ability to form the lowest energy 6HB structure at the pore perimeter, but not at sites of membrane apposition, would drive the pre-bundle incorporation into a nascent pore (Fig. 3). The limitation of this model is that it requires a large number of activated fusion proteins in the vicinity of a pore and is applicable only to proteins that cannot form $6 \mathrm{HBs}$ prior to membrane merger.

Recent work has challenged a common view that several proteins are required to form a functional fusion pore. Based on measurements of infectivity as a function of the ratio of the wild-type to a dominant-negative mutant of HIV-1 Env incorporated into virions, Yang and co-authors concluded that a single Env may mediate productive entry [32]. However, this conclusion is model-dependent. The more rigorous theoretical analysis of the above data yielded a greater number of HIV-1 Env (between 5 and 8) in a fusion complex $[158,159]$. Can a single viral protein store sufficient conformational energy to cause fusion? While estimates of the energy required for pore formation are available [160-162], the energy released upon refolding into a complete trimeric hairpin (including possible interactions between MSDs and fusion peptides) has not been determined. It is also not known how efficiently this conformational energy is utilized to restructure lipid bilayers. Regardless of the energy stored in fusion proteins, a single protein might not be able to exert a force to reshape and rupture fluid membranes. There is evidence that, in order to destabilize and merge two bilayers, fusion proteins must first form an oligomeric "fence" that restricts the lateral diffusion of lipids [84].

The controversy around the stoichiometry of fusion complexes suggests that perhaps this problem should be considered in a different context. Viruses often rely on cellular
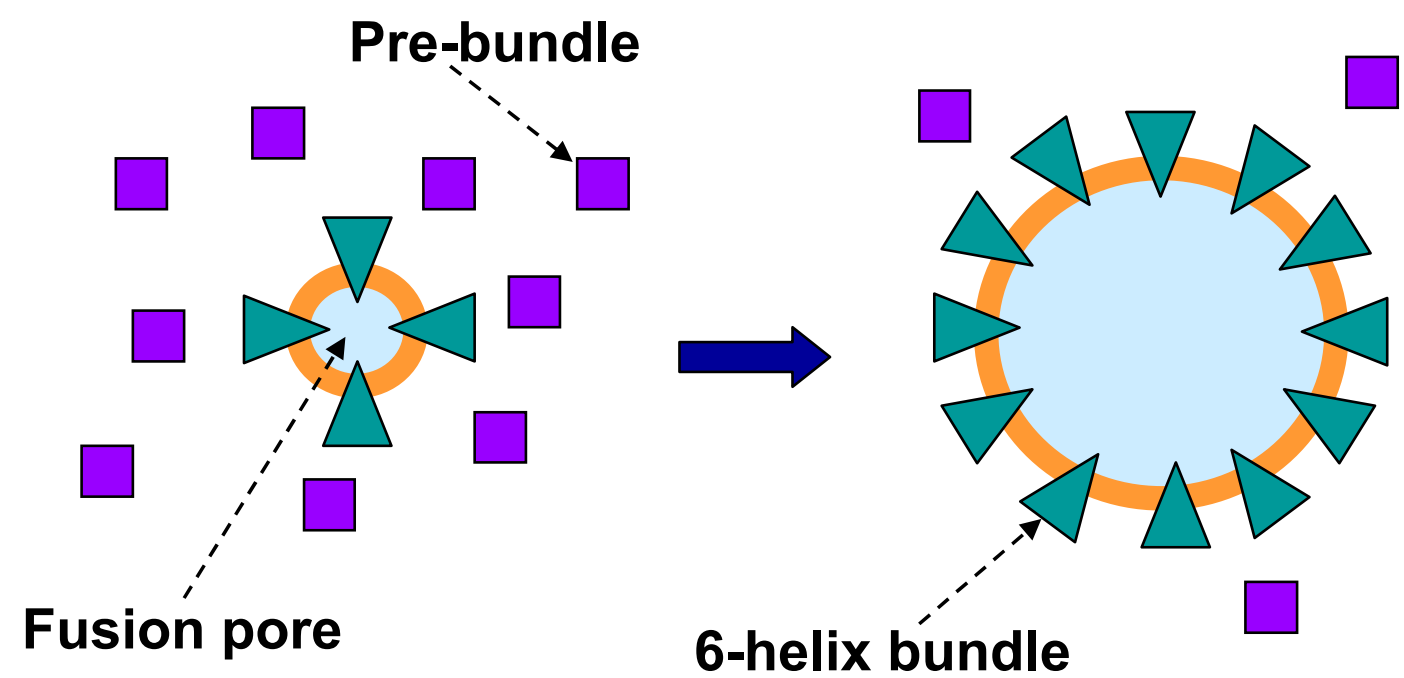

Figure 3

The model for pore expansion via recruitment of fusion proteins (top view). Fusion proteins that require membrane continuity to complete their folding into a 6-helix bundle should accumulate at the perimeter of a fusion pore thereby promoting its enlargement. 
signaling and actin remodeling to enhance infection $[163,164]$. For instance, HIV Env-mediated signaling via CD4 and/or coreceptors has been implicated in productive entry $[18,39,50,165-170]$ and Env-mediated fusion $[131,165,168,171]$. It is thus tempting to speculate that viruses may accomplish the formidable task of creating and expanding a fusion pore by hijacking the cellular machinery. In other words, viral proteins could utilize their conformational energy to promote hemifusion and to create a small pore while relying on a host cell to carry out the energetically costly step of pore dilation. For instance, VSV may undergo low pH-dependent fusion with intralumenal vesicles of early/intermediate endosomes and release its capsid into the cytosol via the constitutive "back-fusion" reaction between intralumenal vesicles and the limiting membrane of a late endosome [42]. However, this two-step fusion entry model for VSV has recently been challenged [172]. Thus, the role of cellular processes in the dilation of viral fusion pores has yet to be unambiguously determined.

The cytoskeleton may facilitate retrovirus entry not only by promoting receptor clustering on the cell surface [131,173-175] or transport of bound viruses along microvilli to the cell body [24], but also by augmenting the fusion and early post-fusion steps $([174,176]$ and references therein). The exploitation of cellular processes to drive the energetically costly step of pore dilation could explain the ability of a few (perhaps even a single $[32,177])$ retroviral Env to initiate infection. Once a hemifusion intermediate or a small fusion pore is formed, viral capsid delivery might be augmented by cytoskeleton rearrangements and/or by membrane trafficking machinery.

\section{Conclusion}

Recent studies of viral fusogens revealed that structurally diverse proteins may have adopted a common "cast-andfold" mechanism to merge membranes. Moreover, the general principles of viral fusion could be shared by proteins responsible for intracellular and developmental fusion $[178,179]$. This common mechanism is likely dictated by the physical properties of lipid bilayers and by the necessity to follow the least energy-costly membrane restructuring pathway leading to fusion without disrupting the membrane barrier function. While structures of the ectodomains or the core fragments of viral proteins showed that these proteins undergo major restructuring that culminates in formation of a trimeric hairpin, the actual refolding pathways remained conjectural. Functional studies demonstrated that viral fusion progresses through a number of distinct, reversible and increasingly unfavorable steps. The notion that formation, and especially enlargement of fusion pores, is an uphill process changes our views on how viral proteins may function. The increasing cost of forming and enlarging fusion pores indicates that viral fusogens should form oligomeric complexes capable of exerting an increasing force as fusion progresses to completion. In addition, viruses may rely on cellular machinery to enlarge fusion pores and release their capsid into the cytosol. Advances in understanding both the molecular details and unifying principles of viral protein-mediated fusion should help identify new targets for antiviral therapy and vaccine development.

\section{Abbreviations}

6HB: six-helix bundle structure; ASLV: Avian Sarcoma and Leukosis Virus; Env: envelope glycoprotein; GPI: glycosylphosphatidylinositol; HR1 and HR2: helical heptad repeat 1 and 2 domains of class I viral fusion proteins; LAS: a lipid-arrested stage of fusion; MLV: Murine Leukemia Virus; MPER: membrane-proximal external domain of a fusion protein; MSD: membrane-spanning domain; SU and TM: surface and transmembrane subunits, respectively, of a fusion protein; TAS: a temperature-arrested stage of fusion; VSV: Vesicular Stomatitis Virus.

\section{Competing interests}

The author declares that they have no competing interests.

\section{Acknowledgements}

The author would like to thank Dr. Kosuke Miyauchi for critical reading of the manuscript and stimulating discussions. This work was supported by NIH R01 grants GM054787 and AI053668.

\section{References}

I. White JM, Delos SE, Brecher M, Schornberg K: Structures and mechanisms of viral membrane fusion proteins: multiple variations on a common theme. Crit Rev Biochem Mol Biol 2008, 43:189-219.

2. Harrison SC: Viral membrane fusion. Nat Struct Mol Biol 2008, I 5:690-698.

3. Kielian M, Rey FA: Virus membrane-fusion proteins: more than one way to make a hairpin. Nat Rev Microbiol 2006, 4:67-76.

4. Lamb RA, Jardetzky TS: Structural basis of viral invasion: lessons from paramyxovirus F. Curr Opin Struct Biol 2007, I 7:427-436.

5. Roche S, Albertini AA, Lepault J, Bressanelli S, Gaudin Y: Structures of vesicular stomatitis virus glycoprotein: membrane fusion revisited. Cell Mol Life Sci 2008, 65:1716-1728.

6. Weissenhorn W, Hinz A, Gaudin Y: Virus membrane fusion. FEBS Lett 2007, 58 I:2 I50-2।55.

7. Chernomordik LV, Melikyan GB, Chizmadzhev YA: Biomembrane fusion: a new concept derived from model studies using two interacting planar lipid bilayers. Biochim Biophys Acta I987, 906:309-352.

8. Kozlov MM, Markin VS: Possible mechanism of membrane fusion. Biofizika 1983, 28(2):242-247.

9. Kozlov MM, Leikin SL, Chernomordik LV, Markin VS, Chizmadzhev YA: Stalk mechanism of vesicle fusion. Intermixing of aqueous contents. Eur Biophys J 1989, I7:121-129.

10. Chernomordik LV, Kozlov MM: Membrane hemifusion: crossing a chasm in two leaps. Cell 2005, I 23:375-382.

II. Cohen FS, Markosyan RM, Melikyan GB: The process of membrane fusion: nipples, hemifusion, pores, and pore growth. Curr Top Membranes 2002, 52:501-529.

12. Chernomordik LV, Zimmerberg J: Bending membranes to the task: structural intermediates in bilayer fusion. Curr Opin Struct Biol 1995, 5:541-547.

13. Kielian M: Class II virus membrane fusion proteins. Virology 2006, 344:38-47. 
14. Durell SR, Martin I, Ruysschaert JM, Shai Y, Blumenthal R: What studies of fusion peptides tell us about viral envelope glycoprotein-mediated membrane fusion (review). Mol Membr Biol 1997, I4:97-II2.

15. Carr CM, Kim PS: A spring-loaded mechanism for the conformational change of influenza hemagglutinin. Cell 1993, 73:823-832.

16. Eckert DM, Kim PS: Mechanisms of Viral Membrane Fusion and Its Inhibition. Annu Rev Biochem 200I, 70:777-8I0.

17. Skehel JJ, Wiley DC: Coiled coils in both intracellular vesicle and viral membrane fusion. Cell 1998, 95:87I-874.

18. Gallo SA, Finnegan CM, Viard M, Raviv Y, Dimitrov A, Rawat SS, Puri A, Durell S, Blumenthal R: The HIV Env-mediated fusion reaction. Biochim Biophys Acta 2003, I 6 I 4:36-50.

19. Skehel J], Wiley DC: Receptor binding and membrane fusion in virus entry: the influenza hemagglutinin. Annu Rev Biochem 2000, 69:531-569.

20. Roche S, Gaudin Y: Characterization of the equilibrium between the native and fusion-inactive conformation of rabies virus glycoprotein indicates that the fusion complex is made of several trimers. Virology 2002, 297: | 28-I35.

21. Blumenthal R, Bali-Puri A, Walter A, Covell D, Eidelman O: pHdependent fusion of vesicular stomatitis virus with Vero cells. Measurement by dequenching of octadecyl rhodamine fluorescence. J Biol Chem 1987, 262:136|4-13619.

22. Blumenthal R, Clague MJ, Durell SR, Epand RM: Membrane fusion. Chem Rev 2003, I 03:53-69.

23. Chernomordik LV, Zimmerberg J, Kozlov MM: Membranes of the world unite! J Cell Biol 2006, I 75:20I-207.

24. Lehmann MJ, Sherer NM, Marks CB, Pypaert M, Mothes W: Actinand myosin-driven movement of viruses along filopodia precedes their entry into cells. J Cell Biol 2005, I 70:3 I 7-325.

25. Chandran K, Sullivan NJ, Felbor U, Whelan SP, Cunningham JM: Endosomal proteolysis of the Ebola virus glycoprotein is necessary for infection. Science 2005, 308: I643-I645.

26. Schornberg K, Matsuyama S, Kabsch K, Delos S, Bouton A, White J: Role of endosomal cathepsins in entry mediated by the Ebola virus glycoprotein. J Virol 2006, 80:4174-4I78.

27. Hsieh SC, Liu IJ, King CC, Chang GJ, Wang WK: A strong endoplasmic reticulum retention signal in the stem-anchor region of envelope glycoprotein of dengue virus type $\mathbf{2}$ affects the production of virus-like particles. Virology 2008 , 374:338-350.

28. Voisset C, Dubuisson J: Functional hepatitis $\mathbf{C}$ virus envelope glycoproteins. Biol Cell 2004, 96:4I3-420.

29. Henderson HI, Hope TJ: The temperature arrested intermediate of virus-cell fusion is a functional step in HIV infection. Virol ] 2006, 3:36.

30. Platt EJ, Durnin JP, Kabat D: Kinetic factors control efficiencies of cell entry, efficacies of entry inhibitors, and mechanisms of adaptation of human immunodeficiency virus. J Virol 2005, 79:4347-4356.

31. Safarian D, Carnec X, Tsamis F, Kajumo F, Dragic T: An anti-CCR5 monoclonal antibody and small molecule CCR5 antagonists synergize by inhibiting different stages of human immunodeficiency virus type I entry. Virology 2006, 352:477-484.

32. Yang X, Kurteva S, Ren X, Lee S, Sodroski J: Stoichiometry of envelope glycoprotein trimers in the entry of human immunodeficiency virus type I. J Virol 2005, 79:12 I32-12147.

33. Daecke J, Fackler OT, Dittmar MT, Krausslich HG: Involvement of clathrin-mediated endocytosis in human immunodeficiency virus type I entry. J Virol 2005, 79:I58|-I594.

34. Tobiume M, Lineberger JE, Lundquist CA, Miller MD, Aiken C: Nef does not affect the efficiency of human immunodeficiency virus type I fusion with target cells. J Virol 2003, 77:10645-10650.

35. Cavrois M, De Noronha C, Greene WC: A sensitive and specific enzyme-based assay detecting HIV-I virion fusion in primary T lymphocytes. Nat Biotechnol 2002, 20:1 I5I-I I54.

36. Kolokoltsov AA, Davey RA: Rapid and sensitive detection of retrovirus entry by using a novel luciferase-based content-mixing assay. J Virol 2004, 78:5 I24-5I32.

37. Saeed MF, Kolokoltsov AA, Davey RA: Novel, rapid assay for measuring entry of diverse enveloped viruses, including HIV and rabies. I Virol Methods 2006, I35:|43-I50.
38. Brandenburg $B$, Zhuang $X$ : Virus trafficking - learning from single-virus tracking. Nat Rev Microbiol 2007, 5: 197-208.

39. Marsh M, Helenius A: Virus entry: open sesame. Cell 2006 , I 24:729-740.

40. Sieczkarski SB, Whittaker GR: Dissecting virus entry via endocytosis. J Gen Virol 2002, 83: I 535-I545.

4I. Smith $A E$, Helenius $A$ : How viruses enter animal cells. Science 2004, 304:237-242.

42. Le Blanc I, Luyet PP, Pons V, Ferguson C, Emans N, Petiot A, Mayran N, Demaurex N, Fauré J, Sadoul R, Parton RG, Gruenberg J: Endosome-to-cytosol transport of viral nucleocapsids. Nat Cell Biol 2005, 7:653-664

43. Sakai T, Ohuchi M, Imai M, Mizuno T, Kawasaki K, Kuroda K, Yamashina S: Dual wavelength imaging allows analysis of membrane fusion of influenza virus inside cells. J Virol 2006, 80:2013-2018.

44. Lakadamyali M, Rust MJ, Babcock HP, Zhuang X: Visualizing infection of individual influenza viruses. Proc Natl Acad Sci USA 2003, I 00:9280-9285.

45. Lakadamyali M, Rust MJ, Zhuang X: Ligands for clathrin-mediated endocytosis are differentially sorted into distinct populations of early endosomes. Cell 2006, I24:997-I009.

46. Sieczkarski SB, Whittaker GR: Differential requirements of Rab5 and Rab7 for endocytosis of influenza and other enveloped viruses. Traffic 2003, 4:333-343.

47. Vonderheit A, Helenius A: Rab7 associates with early endosomes to mediate sorting and transport of Semliki forest virus to late endosomes. PLoS Biol 2005, 3:e233.

48. Markosyan RM, Cohen FS, Melikyan GB: Time-resolved imaging of HIV-I Env-mediated lipid and content mixing between a single virion and cell membrane. Mol Biol Cell 2005 , 16:5502-55।3.

49. Melikyan GB, Barnard RJ, Abrahamyan LG, Mothes W, Young JA: Imaging individual retroviral fusion events: from hemifusion to pore formation and growth. Proc Natl Acad Sci USA 2005, 1 02:8728-8733.

50. Marsh M, Pelchen-Matthews A: Endocytosis in viral replication. Traffic 2000, I:525-532

5I. Berger EA, Murphy PM, Farber JM: Chemokine receptors as HIVI coreceptors: roles in viral entry, tropism, and disease. Annu Rev Immunol 1999, I 7:657-700.

52. Lamb RA, Paterson RG, Jardetzky TS: Paramyxovirus membrane fusion: lessons from the $F$ and $\mathrm{HN}$ atomic structures. Virology 2006, 344:30-37

53. Diaz-Griffero F, Hoschander SA, Brojatsch J: Endocytosis is a critical step in entry of subgroup $B$ avian leukosis viruses. J Virol 2002, 76: I2866-I2876.

54. Barnard RJ, Narayan S, Dornadula G, Miller MD, Young JA: Low pH is required for avian sarcoma and leukosis virus Env-dependent viral penetration into the cytosol and not for viral uncoating. I Virol 2004, 78: 10433-1044I.

55. Matsuyama S: Sequential roles of receptor binding and low pH in forming prehairpin and hairpin conformations of a retroviral envelope glycoprotein. Journal of Virology 2004, 78:820I-9.

56. Melikyan GB, Barnard RJ, Markosyan RM, Young JA, Cohen FS: Low pH Is Required for Avian Sarcoma and Leukosis Virus EnvInduced Hemifusion and Fusion Pore Formation but Not for Pore Growth. J Virol 2004, 78:3753-3762.

57. Mothes W, AL Boerger, S Narayan, JM Cunningham, JAT Young: Retroviral entry mediated by receptor priming and low $\mathrm{pH}$ triggering of an envelope glycoprotein. Cell 2000, 1 03:679-689.

58. Netter RC, Amberg SM, Balliet JW, Biscone MJ, Vermeulen A, Earp LJ, White JM, Bates P: Heptad repeat 2-based peptides inhibit avian sarcoma and leukosis virus subgroup a infection and identify a fusion intermediate. J Virol 2004, 78: I3430-13439.

59. Smith JG, Mothes W, Blacklow SC, Cunningham JM: The mature avian leukosis virus subgroup $A$ envelope glycoprotein is metastable, and refolding induced by the synergistic effects of receptor binding and low pH is coupled to infection. J Virol 2004, 78: |403-|4|0.

60. Doms RW: Beyond receptor expression: the influence of receptor conformation, density, and affinity in HIV-I infection. Virology 2000, 276:229-237.

61. Tamm LK: Hypothesis: spring-loaded boomerang mechanism of influenza hemagglutinin-mediated membrane fusion. Biochim Biophys Acta 2003, I 6 | 4: |4-23. 
62. Durrer P, Galli C, Hoenke S, Corti C, Gluck R, Vorherr T, Brunner J: $\mathrm{H}+$-induced membrane insertion of influenza virus hemagglutinin involves the HA2 amino-terminal fusion peptide but not the coiled coil region. B Biol Chem 1996, 27 I: I34 I7-I342I.

63. Durrer P, Gaudin Y, Ruigrok RW, Graf R, Brunner J: Photolabeling identifies a putative fusion domain in the envelope glycoprotein of rabies and vesicular stomatitis viruses. J Biol Chem 1995 270: 17575-1758I.

64. Pak CC, Puri A, Blumenthal R: Conformational changes and fusion activity of vesicular stomatitis virus glycoprotein: [125I]iodonaphthyl azide photolabeling studies in biological membranes. Biochemistry 1997, 36:8890-8896.

65. Stegmann T, Delfino JM, Richards FM, Helenius A: The HA2 subunit of influenza hemagglutinin inserts into the target membrane prior to fusion. J Biol Chem I99I, 266: |8404-I84I0.

66. Gibbons DL, Erk I, Reilly B, Navaza J, Kielian M, Rey FA, Lepault J: Visualization of the target-membrane-inserted fusion protein of Semliki Forest virus by combined electron microscopy and crystallography. Cell 2003, I | 4:573-583.

67. Tristram-Nagle S, Nagle JF: HIV-I fusion peptide decreases bending energy and promotes curved fusion intermediates. Biophys J 2007, 93:2048-2055.

68. Tamm LK, Han X: Viral fusion peptides: a tool set to disrupt and connect biological membranes. Biosci Rep 2000, 20:50I-5I8.

69. Epand RM: Fusion peptides and the mechanism of viral fusion. Biochim Biophys Acta 2003, 16 14:116-121.

70. Dimitrov AS, Rawat SS, Jiang S, Blumenthal R: Role of the fusion peptide and membrane-proximal domain in HIV-I envelope glycoprotein-mediated membrane fusion. Biochemistry 2003, 42: $14150-14 \mid 58$

7I. Qiao H, Armstrong RT, Melikyan GB, Cohen FS, White JM: A specific point mutant at position I of the influenza hemagglutinin fusion peptide displays a hemifusion phenotype [In Process Citation]. Mol Biol Cell 1999, 10:2759-2769.

72. Steinhauer DA, Wharton SA, Skehel JJ, Wiley DC: Studies of the membrane fusion activities of fusion peptide mutants of influenza virus hemagglutinin. J Virol 1995, 69:6643-6651.

73. Hernandez LD, White JM: Mutational Analysis of the Candidate Internal Fusion Peptide of the Avian Leukosis and Sarcoma Virus Subgroup A Envelope Glycoprotein. J Virol 1998, 72:3259-3267.

74. Ito H, Watanabe S, Sanchez A, Whitt MA, Kawaoka Y: Mutational analysis of the putative fusion domain of Ebola virus glycoprotein. J Virol 1999, 73:8907-89/2.

75. Shome SG, Kielian M: Differential roles of two conserved glycine residues in the fusion peptide of Semliki Forest virus. Virology 200I, 279: 146-160.

76. Freed EO, Delwart EL, Buchschacher GL Jr, Panganiban AT: A mutation in the human immunodeficiency virus type I transmembrane glycoprotein gp4I dominantly interferes with fusion and infectivity. Proc Natl Acad Sci USA 1992, 89:70-74.

77. Levy-Mintz $P$, Kielian M: Mutagenesis of the putative fusion domain of the Semliki Forest virus spike protein. J Virol 199I, 65:4292-4300.

78. Borrego-Diaz E, Peeples ME, Markosyan RM, Melikyan GB, Cohen FS: Completion of trimeric hairpin formation of influenza virus hemagglutinin promotes fusion pore opening and enlargement. Virology 2003, 3 16:234-244.

79. Lu M, Stoller MO, Wang S, Liu J, Fagan MB, Nunberg JH: Structural and Functional Analysis of Interhelical Interactions in the Human Immunodeficiency Virus Type I gp4I Envelope Glycoprotein by Alanine-Scanning Mutagenesis. J Virol 200I, 75: III46-11156

80. Weng $Y$, Weiss $C D$ : Mutational analysis of residues in the coiled-coil domain of human immunodeficiency virus type I transmembrane protein gp4I. I Virol 1998, 72:9676-9682

81. West DS, Sheehan MS, Segeleon PK, Dutch RE: Role of the simian virus 5 fusion protein $\mathbf{N}$-terminal coiled-coil domain in folding and promotion of membrane fusion. I Virol 2005 79: $|543-| 55 \mid$.

82. Liao M, Kielian M: Functions of the stem region of the Semliki Forest virus fusion protein during virus fusion and assembly. J Virol 2006, 80: I |362-I I369.
83. Liao M, Kielian M: Domain III from class II fusion proteins functions as a dominant-negative inhibitor of virus membrane fusion. J Cell Biol 2005, I 7 I: I I I-120.

84. Chernomordik LV, Frolov VA, Leikina E, Bronk P, Zimmerberg J: The pathway of membrane fusion catalyzed by influenza hemagglutinin: restriction of lipids, hemifusion, and lipidic fusion pore formation. / Cell Biol 1998, I40:|369-|382.

85. Markosyan RM, Melikyan GB, Cohen FS: Evolution of intermediates of influenza virus hemagglutinin-mediated fusion revealed by kinetic measurements of pore formation. Biophys J 200I, 80:8I2-82।.

86. Markosyan RM, Kielian M, Cohen FS: Fusion induced by a class II viral fusion protein, semliki forest virus $\mathrm{EI}$, is dependent on the voltage of the target cell. J Virol 2007, 8I: I I 2 I8-I I 225.

87. Gaudin Y: Rabies virus-induced membrane fusion pathway. Cell Biol 2000, 150:60I-612

88. Stiasny K, Heinz FX: Effect of membrane curvature-modifying lipids on membrane fusion by tick-borne encephalitis virus. J Virol 2004, 78:8536-8542.

89. Zaitseva E, Mittal A, Griffin DE, Chernomordik LV: Class II fusion protein of alphaviruses drives membrane fusion through the same pathway as class I proteins. J Cell Biol 2005, 169:167-I77.

90. Freed EO: HIV-I and the host cell: an intimate association. Trends Microbiol 2004, I 2: 170-177.

91. Chen B, Vogan EM, Gong H, Skehel JJ, Wiley DC, Harrison SC: Structure of an unliganded simian immunodeficiency virus gp I 20 core. Nature 2005, 433:834-84I.

92. Xiao $X$, Norwood $D$, Feng $Y R$, Moriuchi $M$, Jones-Trower $A$, Stantchev TS, Moriuchi H, Broder CC, Dimitrov DS: Inefficient formation of a complex among CXCR4, CD4 and gp I 20 in U937 clones resistant to X4 gp I 20-gp 4 I-mediated fusion. Exp Mol Pathol 2000, 68:139-146.

93. Trkola A, Dragic T, Arthos J, Binley JM, Olson WC, Allaway GP, Cheng-Mayer C, Robinson J, Maddon PJ, Moore JP: CD4-dependent, antibody-sensitive interactions between HIV-I and its co- receptor CCR-5 [see comments]. Nature 1996, 384: $184-187$

94. Wu L, Gerard NP, Wyatt R, Choe H, Parolin C, Ruffing N, Borsetti A, Cardoso AA, Desjardin E, Newman W, Gerard C, Sodroski J: CD4-induced interaction of primary HIV-I gp I 20 glycoproteins with the chemokine receptor CCR-5. Nature 1996, 384: $179-183$

95. Sattentau QJ, Moore JP: Conformational changes induced in the human immunodeficiency virus envelope glycoprotein by soluble CD4 binding. J Exp Med 1991, 174:407-4I5.

96. Salzwedel K, Smith ED, Dey B, Berger EA: Sequential CD4-coreceptor interactions in human immunodeficiency virus type I Env function: soluble CD4 activates Env for coreceptordependent fusion and reveals blocking activities of antibodies against cryptic conserved epitopes on gp I20. J Virol 2000, 74:326-333.

97. Kwong PD, Wyatt R, Robinson J, Sweet RW, Sodroski J, Hendrickson WA: Structure of an HIV gp/20 envelope glycoprotein in complex with the CD4 receptor and a neutralizing human antibody. Nature 1998, 393:648-659.

98. Gallo SA, Reeves JD, Garg H, Foley B, Doms RW, Blumenthal R: Kinetic studies of HIV-I and HIV-2 envelope glycoproteinmediated fusion. Retrovirology 2006, 3:90.

99. Earl PL, Doms RW, Moss B: Multimeric CD4 binding exhibited by human and simian immunodeficiency virus envelope protein dimers. J Virol $1992,66: 56|0-56| 4$

100. Kim M, Chen B, Hussey RE, Chishti Y, Montefiori D, Hoxie JA, Byron O, Campbell G, Harrison SC, Reinherz EL: The stoichiometry of trimeric SIV glycoprotein interaction with CD4 differs from that of anti-envelope antibody Fab fragments. I Biol Chem 200I, 276:42667-42676.

10I. Salzwedel K, Berger EA: Cooperative subunit interactions within the oligomeric envelope glycoprotein of HIV-I: functional complementation of specific defects in gp/20 and gp4 I. Proc Natl Acad Sci USA 2000, 97: I 2794- 2799.

102. Kuhmann SE, Platt EJ, Kozak SL, Kabat D: Cooperation of multiple CCR5 coreceptors is required for infections by human immunodeficiency virus type I. J Virol 2000, 74:7005-70I5.

103. Platt EJ, Durnin JP, Shinde U, Kabat D: An allosteric rheostat in HIV-I gpI20 reduces CCR5 stoichiometry required for 
membrane fusion and overcomes diverse entry limitations. J Mol Biol 2007, 374:64-79.

104. Bourgeois R, Mercier J, Paquette-Brooks I, Cohen EA: Association between disruption of CD4 receptor dimerization and increased human immunodeficiency virus type I entry. Retrovirology 2006, 3:31.

105. Chelli M, Alizon M: Rescue of HIV-I receptor function through cooperation between different forms of the CCR5 chemokine receptor. J Biol Chem 2002, 277:39388-39396.

106. Barbouche R, Miquelis R, Jones IM, Fenouillet E: Protein-disulfide isomerase-mediated reduction of two disulfide bonds of HIV envelope glycoprotein I 20 occurs post-CXCR4 binding and is required for fusion. $\mathrm{J} \mathrm{Biol} \mathrm{Chem} \mathrm{2003,} \mathrm{278:313I-3I36.}$

107. Gallina A, Hanley TM, Mandel R, Trahey M, Broder CC, Viglianti GA, Ryser HJ: Inhibitors of protein disulfide isomerase (PDI) prevent cleavage of disulfide bonds in receptor-bound gp I 20 and prevent HIV-I entry. I Biol Chem 2002, 277:50579-50588.

108. Markovic I, Stantchev TS, Fields KH, Tiffany LJ, Tomic M, Weiss CD, Broder CC, Strebel K, Clouse KA: Thiol/disulfide exchange is a prerequisite for CXCR4-tropic HIV-I envelope-mediated Tcell fusion during viral entry. Blood 2004, I 03: I 586-I 594.

109. Ou W, Silver J: Role of protein disulfide isomerase and other thiol-reactive proteins in HIV-I envelope protein-mediated fusion. Virology 2006, 350:406-4I7.

I I0. Chien MP, Jiang S, Chang DK: The function of coreceptor as a basis for the kinetic dissection of HIV type I envelope protein-mediated cell fusion. Faseb J 2008, 22: I I79-I I 92.

I II. Fischer PB, Karlsson GB, Dwek RA, Platt FM: N-butyldeoxynojirimycin-mediated inhibition of human immunodeficiency virus entry correlates with impaired gp/20 shedding and gp4 I exposure. J Virol 1996, 70:7I53-7I60.

I I2. Willey RL, Martin MA, Peden KW: Increase in soluble CD4 binding to and CD4-induced dissociation of gp 120 from virions correlates with infectivity of human immunodeficiency virus type I. J Virol 1994, 68:1029-1039.

I I3. Fu YK, Hart TK, Jonak ZL, Bugelski PJ: Physicochemical dissociation of CD4-mediated syncytium formation and shedding of human immunodeficiency virus type I gpI20. J Virol I993, 67:3818-3825

I 14. Thali M, Furman C, Helseth E, Repke H, Sodroski J: Lack of correlation between soluble CD4-induced shedding of the human immunodeficiency virus type I exterior envelope glycoprotein and subsequent membrane fusion events. J Virol 1992, 66:55 16-5524

115. Abrahamyan LG, Markosyan RM, Moore JP, Cohen FS, Melikyan GB: Human immunodeficiency virus type I Env with an intersubunit disulfide bond engages coreceptors but requires bond reduction after engagement to induce fusion. J Virol 2003, 77:5829-5836.

I 16. Finnegan CM, Berg W, Lewis GK, DeVico AL: Antigenic properties of the human immunodeficiency virus transmembrane glycoprotein during cell-cell fusion. J Virol 2002, 76: $12123-12134$.

I17. Dimitrov AS, Louis JM, Bewley CA, Clore GM, Blumenthal R: Conformational changes in HIV-I gp4I in the course of HIV-I envelope glycoprotein-mediated fusion and inactivation. Biochemistry 2005, 44: |247|-|2479.

I 18. Golding H, Zaitseva M, de Rosny E, King LR, Manischewitz J, Sidorov I, Gorny MK, Zolla-Pazner S, Dimitrov DS, Weiss CD: Dissection of human immunodeficiency virus type I entry with neutralizing antibodies to gp4I fusion intermediates. J Virol 2002, 76:6780-6790

I19. Koshiba T, Chan DC: The prefusogenic intermediate of HIV-I gp4l contains exposed C-peptide regions. I Biol Chem 2002, 278:7573-7579.

120. Dimitrov AS, Jacobs A, Finnegan CM, Stiegler G, Katinger H, Blumenthal R: Exposure of the Membrane-Proximal External Region of HIV-I gp4I in the Course of HIV-I Envelope Glycoprotein-Mediated Fusion. Biochemistry 2007, 46:1398-|40I.

12I. Abrahamyan LG, Mkrtchyan SR, Binley J, Lu M, Melikyan GB, Cohen FS: The cytoplasmic tail slows the folding of human immunodeficiency virus type I Env from a late prebundle configuration into the six-helix bundle. I Virol 2005, 79: I06-II5

122. Gallo SA, Clore GM, Louis JM, Bewley CA, Blumenthal R: Temperature-dependent intermediates in HIV-I envelope glycoprotein-mediated fusion revealed by inhibitors that target $\mathbf{N}$ - and C-terminal helical regions of HIV-I gp4I. Biochemistry 2004, 43:8230-8233.

123. Markosyan RM, Cohen FS, Melikyan GB: HIV-I envelope proteins complete their folding into six-helix bundles immediately after fusion pore formation. Mol Biol Cell 2003, I4:926-938.

124. Mkrtchyan SR, Markosyan RM, Eadon MT, Moore JP, Melikyan GB, Cohen FS: Ternary complex formation of human immunodeficiency virus type I Env, CD4, and chemokine receptor captured as an intermediate of membrane fusion. J Virol 2005, 79: $11161-11169$

125. de Rosny E, Vassell R, Jiang S, Kunert R, Weiss CD: Binding of the 2F5 monoclonal antibody to native and fusion-intermediate forms of human immunodeficiency virus type I gp4 I: implications for fusion-inducing conformational changes. J Virol 2004, 78:2627-2631.

126. Furuta RA, Wild CT, Weng Y, Weiss CD: Capture of an early fusion-active conformation of HIV-I gp4I. Nat Struct Biol I998, 5:276-279.

127. He Y, Vassell R, Zaitseva M, Nguyen N, Yang Z, Weng Y, Weiss CD: Peptides trap the human immunodeficiency virus type I envelope glycoprotein fusion intermediate at two sites. J Virol 2003, 77:1666-I67I.

128. Kilgore NR, Salzwedel K, Reddick M, Allaway GP, Wild CT: Direct evidence that $C$-peptide inhibitors of human immunodeficiency virus type I entry bind to the gp4 I N-helical domain in receptor-activated viral envelope. I Virol 2003, 77:7669-7672

129. Melikyan GB, Egelhofer M, von Laer D: Membrane-anchored inhibitory peptides capture human immunodeficiency virus type I gp4 I conformations that engage the target membrane prior to fusion. J Virol 2006, 80:3249-3258

130. Melikyan GB, Markosyan RM, Hemmati H, Delmedico MK, Lambert DM, Cohen FS: Evidence that the transition of HIV-I gp4 I into a six-helix bundle, not the bundle configuration, induces membrane fusion. I Cell Biol 2000, I 5 I:413-424.

I3I. Gallo SA, Puri A, Blumenthal R: HIV-I gp4 I six-helix bundle formation occurs rapidly after the engagement of gp I 20 by CXCR4 in the HIV-I Env-mediated fusion process. Biochemistry 200I, 40:I223I-I2236.

132. Chan DC, Kim PS: HIV entry and its inhibition. Cell 1998, 93:68I-684.

I33. Kliger Y, Shai Y: Inhibition of HIV-I entry before gp4 I folds into its fusion-active conformation. I Mol Biol 2000, 295: I63-168.

134. Frey S, Marsh M, Gunther S, Pelchen-Matthews A, Stephens $P$, Ortlepp S, Stegmann T: Temperature dependence of cell-cell fusion induced by the envelope glycoprotein of human immunodeficiency virus type I. J Virol |995, 69:|462-|472.

135. Jernigan KM, Blumenthal R, Puri A: Varying effects of temperature, $\mathrm{Ca}(2+)$ and cytochalasin on fusion activity mediated by human immunodeficiency virus type I and type 2 glycoproteins. FEBS Lett 2000, 474:246-25I.

136. Chernomordik L, Kozlov MM, Zimmerberg J: Lipids in biological membrane fusion. J Membr Biol 1995, I 46: I- I4.

137. Egelhofer M, Brandenburg G, Martinius H, Schult-Dietrich P, Melikyan G, Kunert R, Baum C, Choi I, Alexandrov A, von Laer D: Inhibition of human immunodeficiency virus type $I$ entry in cells expressing gp4I-derived peptides. I Virol 2004, 78:568-575.

138. Hildinger M, Dittmar MT, Schult-Dietrich P, Fehse B, Schnierle BS, Thaler S, Stiegler G, Welker R, von Laer D: Membrane-anchored peptide inhibits human immunodeficiency virus entry. J Virol 200I, 75:3038-3042.

139. Raviv Y, Viard M, Bess J Jr, Blumenthal R: Quantitative measurement of fusion of HIV-I and SIV with cultured cells using photosensitized labeling. Virology 2002, 293:243-25I.

140. Blacklow SC, Lu M, Kim PS: A trimeric subdomain of the simian immunodeficiency virus envelope glycoprotein. Biochemistry 1995, 34: |4955-|4962.

14I. Weissenhorn W, Wharton SA, Calder LJ, Earl PL, Moss B, Aliprandis E, Skehel JJ, Wiley DC: The ectodomain of HIV-I env subunit gp4 I forms a soluble, alpha-helical, rod-like oligomer in the absence of gp 120 and the $\mathbf{N}$-terminal fusion peptide. Embo J 1996, I5:1507-15|4.

142. Munoz-Barroso I, Salzwedel K, Hunter E, Blumenthal R: Role of the membrane-proximal domain in the initial stages of human immunodeficiency virus type I envelope glycoprotein-mediated membrane fusion. J Virol 1999, 73:6089-6092. 
143. Bellamy-McIntyre AK, Lay CS, Baar S, Maerz AL, Talbo GH, Drummer $\mathrm{HE}$, Poumbourios P: Functional links between the fusion peptide-proximal polar segment and membrane-proximal region of human immunodeficiency virus gp4l in distinct phases of membrane fusion. J Biol Chem 2007, 282:23 I04-23 I I6.

144. Markosyan RM, Bates P, Cohen FS, Melikyan GB: A study of low pH-induced refolding of Env of avian sarcoma and leukosis virus into a six-helix bundle. Biophys J 2004, 87:329l-3298.

145. Russell C], Jardetzky TS, Lamb RA: Membrane fusion machines of paramyxoviruses: capture of intermediates of fusion. Embo J 200I, 20:4024-4034.

146. Cohen FS, Melikyan GB: The energetics of membrane fusion from binding, through hemifusion, pore formation, and pore enlargement. J Membr Biol 2004, I 99: I- I4.

147. Leikina E, Chernomordik LV: Reversible merger of membranes at the early stage of influenza hemagglutinin-mediated fusion. Mol Biol Cell 2000, I I:2359-237I

148. Markosyan RM, Cohen FS, Melikyan GB: The lipid-anchored ectodomain of influenza virus hemagglutinin (GPI-HA) is capable of inducing nonenlarging fusion pores. Mol Biol Cell 2000, I I:I I43-1 I52.

149. Melikyan GB, Markosyan RM, Roth MG, Cohen FS: A point mutation in the transmembrane domain of the hemagglutinin of influenza virus stabilizes a hemifusion intermediate that can transit to fusion. Mol Biol Cell 2000, I I:3765-3775

I50. Munoz-Barroso I, Durell S, Sakaguchi K, Appella E, Blumenthal R: Dilation of the human immunodeficiency virus-I envelope glycoprotein fusion pore revealed by the inhibitory action of a synthetic peptide from gp4 I. I Cell Biol 1998, I40:3 I5-323.

I5I. Frolov V, Cho M, Reese TS, Zimmerberg J: Both hemifusion and fusion pores are induced by GPI-linked influenza hemagglutinin. Traffic 2000, I:622-630.

152. Melikyan GB, Lin S, Roth MG, Cohen FS: Amino acid sequence requirements of the transmembrane and cytoplasmic domains of influenza virus hemagglutinin for viable membrane fusion. Mol Biol Cell 1999, 10:1821-1836.

153. Danieli T, Pelletier SL, Henis YI, White JM: Membrane fusion mediated by the influenza virus hemagglutinin requires the concerted action of at least three hemagglutinin trimers. Journal of Cell Biology 1996, I33:559-569.

154. Ellens H, Bentz J, Mason D, Zhang F, White JM: Fusion of influenza hemagglutinin-expressing fibroblasts with glycophorin-bearing liposomes: role of hemagglutinin surface density. Biochemistry 1990, 29:9697-9707.

155. Blumenthal R, Sarkar DP, Durell S, Howard DE, Morris Sj: Dilation of the influenza hemagglutinin fusion pore revealed by the kinetics of individual cell-cell fusion events. J Cell Biol 1996, |35:63-7|.

I56. Markovic I, Leikina E, Zhukovsky M, Zimmerberg J, Chernomordik LV: Synchronized activation and refolding of influenza hemagglutinin in multimeric fusion machines. I Cell Biol 200 I, I 55:833-844.

157. Russell C], Jardetzky TS, Lamb RA: Membrane fusion machines of paramyxoviruses: capture of intermediates of fusion. Embo J 2001, 20:4024-4034

158. Klasse PJ: Modeling how many envelope glycoprotein trimers per virion participate in human immunodeficiency virus infectivity and its neutralization by antibody. Virology 2007 , 369:245-262.

159. Magnus C, Rusert P, Bonhoeffer S, Trkola A, Regoes RR: Estimating the stoichiometry of HIV entry. J Virol 2008.

160. Markin VS, Albanesi JP: Membrane fusion: stalk model revisited. Biophys J 2002, 82:693-7I2.

161. Kuzmin PI, Zimmerberg J, Chizmadzhev YA, Cohen FS: A quantitative model for membrane fusion based on low-energy intermediates. Proc Natl Acad Sci USA 2001, 98:7235-7240.

162. Kozlovsky Y, Kozlov MM: Stalk model of membrane fusion: solution of energy crisis. Biophys J 2002, 82:882-895.

163. Radtke K, Dohner K, Sodeik B: Viral interactions with the cytoskeleton: a hitchhiker's guide to the cell. Cell Microbiol 2006, 8:387-400

164. Chami M, Oules B, Paterlini-Brechot P: Cytobiological consequences of calcium-signaling alterations induced by human viral proteins. Biochim Biophys Acta 2006, I 763: I 344-I 362

165. del Real G, Jiménez-Baranda S, Mira E, Lacalle RA, Lucas P, GómezMoutón C, Alegret M, Peña JM, Rodríguez-Zapata M, Alvarez-Mon M,
Martínez-A C, Mañes S: Statins inhibit HIV-I infection by downregulating Rho activity. J Exp Med 2004, 200:54 I-547.

166. Lin YL, Mettling C, Portales P, Reant B, Robert-Hebmann V, Reynes J, Clot J, Corbeau P: The efficiency of R5 HIV-I infection is determined by CD4 T-cell surface CCR5 density through $\mathbf{G}$ alpha i-protein signalling. Aids 2006, 20: |369-1377.

167. Melar M, Ott DE, Hope T]: Physiological levels of virion-associated human immunodeficiency virus type I envelope induce coreceptor-dependent calcium flux. J Virol 2007, 8 I : | 773- I 785

168. Stantchev TS, Markovic I, Telford WG, Clouse KA, Broder CC: The tyrosine kinase inhibitor genistein blocks HIV-I infection in primary human macrophages. Virus Res 2007, I 23: I78-I89.

169. Viard M, Parolini I, Rawat SS, Fecchi K, Sargiacomo M, Puri A, Blumenthal R: The role of glycosphingolipids in HIV signaling, entry and pathogenesis. Glycoconj / 2004, 20:213-222.

170. Grainger DJ, Lever AM: Blockade of chemokine-induced signalling inhibits CCR5-dependent HIV infection in vitro without blocking gp I 20/CCR5 interaction. Retrovirology 2005, 2:23.

17I. Pontow SE, Heyden NV, Wei S, Ratner L: Actin cytoskeletal reorganizations and coreceptor-mediated activation of rac during human immunodeficiency virus-induced cell fusion. J Virol 2004, 78:7|38-7|47.

172. Johannsdottir HK, Mancini R, Kartenbeck J, Amato L, Helenius A Host cell factors and functions involved in Vesicular stomatitis virus entry. J Virol 2008.

173. Viard M, Parolini I, Sargiacomo M, Fecchi K, Ramoni C, Ablan S, Ruscetti FW, Wang JM, Blumenthal R: Role of cholesterol in human immunodeficiency virus type I envelope proteinmediated fusion with host cells. I Virol 2002, 76: I I 584- I I 595.

174. Fackler OT, Krausslich HG: Interactions of human retroviruses with the host cell cytoskeleton. Curr Opin Microbiol 2006, 9:409-4I5.

175. lyengar S, Hildreth JE, Schwartz DH: Actin-dependent receptor colocalization required for human immunodeficiency virus entry into host cells. J Virol 1998, 72:525 I-5255.

176. Naghavi MH, Goff SP: Retroviral proteins that interact with the host cell cytoskeleton. Curr Opin Immunol 2007, 19:402-407.

177. Yang X, Kurteva S, Lee S, Sodroski J: Stoichiometry of antibody neutralization of human immunodeficiency virus type I. J Virol 2005, 79:3500-3508.

178. Jahn R, Lang T, Sudhof TC: Membrane fusion. Cell 2003, I | 2:519-533.

179. Sapir A, Avinoam O, Podbilewicz B, Chernomordik LV: Viral and developmental cell fusion mechanisms: conservation and divergence. Dev Cell 2008, I4:|| |-2I.

Publish with Biomed Central and every scientist can read your work free of charge

"BioMed Central will be the most significant development for disseminating the results of biomedical research in our lifetime. "

Sir Paul Nurse, Cancer Research UK

Your research papers will be:

- available free of charge to the entire biomedical community

- peer reviewed and published immediately upon acceptance

- cited in PubMed and archived on PubMed Central

- yours - you keep the copyright

BioMedcentral 